\title{
Comparative Analysis of Legal Winning Between Islamic Law \& Traditional Law
}

\section{Muhammad Luthfi*) and Lathifah Hanim**)}

*) Student of Master of Law, Faculty of Law, Universitas Islam Sultan Agung Semarang, E-mail: lutvi.ayoze@gmail.com

${ }^{* *}$ ) Faculty of Law Universitas Islam Sultan Agung

\begin{abstract}
.
The purpose of this research is to find out about the application and things related to it, To know the views of Islamic law on marriage, and to find out the views of customary law in Kutuk Village, Undaan District, Kudus Regency about marriage. The research approach method used was sociological juridical. Writing specifications are descriptive analysis, sources and types of data used primary and secondary data. Data collection methods by interview, library research, and using qualitative data analysis methods. The conclusions of this study are: The marriage according to Islamic law is carried out very Islamic and really hopes for the pleasure of Allah SWT without being based on material. Meanwhile, the wedding according to customary law in Kutuk Village, Undaan Subdistrict, Kudus Regency is very close to the Kejawen area of Pati Regency and seems to smell of material existence. The material problem there really determines whether or not a proposal is accepted.
\end{abstract}

Keywords: Marriage; Islamic Law; Customary Law.

\section{Introduction}

Marriage should not be arbitrary, so that the family we aspire to be beautiful, it is necessary to have careful preparation in selecting a partner. Marriage, which is generally for life, requires careful preparation to prepare it, including carefulness in choosing a potential partner. Compatibility becomes necessary to remember to anticipate how to improve the lack of a partner later, for example. Some calculations and considerations for choosing are needed by using the rules that have been determined in regulating life or commonly said by law. ${ }^{1}$

One way of selecting potential partners is by dating. However, keep in mind that Islam does not recognize the term dating and is more about Ta'aruf (acquaintance). ${ }^{2}$ Getting to know the opposite sex does not only involve two people, but also through a more respectful way by involving each other's families in a respectful way too. In this way, it is possible to have security for all parties in smoothing the common mission of continuing to the next stage of marriage. So the acquaintance of getting to know each other is not only between two people but can thoroughly get to know each other between families.

Generally, requests are carried out by men. This does not rule out the women who do it. Traditionally, it was men who knocked on the doors of the

\footnotetext{
1 Muhammad Maulana Firdaus, Studi Perbandingan Alasan Penghapusan Pidana Menurut Kitab Undang-Undang Hukum Pidana (KUHP) dan Hukum Pidana Islam dalam Rangka Pembaharuan Hukum Pidana Nasional, Jurnal Hukum Unissula, Vo. 36, No. 2, 2020, p. 75.

${ }^{2}$ Leylana Hana, Taaruf Proses Perjodohan Sesuai Syari Islam, PT Elex Media Komputindo, Jakarta, 2012, p. 3.
} 
women's houses. Indeed, the customs of a region have differences about it and these differences do not become a serious matter in the legality of their future marriage. Not only about who used to propose and who was proposed, the procession of procedures for the marriage ceremony was different, some through certain ceremonies some were just as ordinary as visiting in general. Every region, even though it adheres to Islam, but in practice it is very likely to be contaminated with local laws. ${ }^{3}$

Based on the description of the background that has been described, the authors formulate the objectives of this study as follows: To find out about the application and matters related to the application; To know the views of Islamic law on marriage and to find out the views of customary law in Indonesia on marriage.

\section{Research methods}

The author in his research uses a sociological juridical approach, namely by analyzing and primarily observing whether a law works or not in society. ${ }^{4}$ The author observes Islamic law and customary law that work in the community of Kutuk Village, Undaan District, Kudus Regency. As for the research specification, the writer uses descriptive analysis by describing the object and then analyzing it. ${ }^{5}$ The author describes the issue of application in the view of Islamic law and customary law and then analyzes it.

Sources and types of data used are primary and secondary data. The method of collecting data is by interviewing sources who are really aware of the problem, literature research includes books of Islamic law (munakahat) and books of customary law as a support, and the data analysis method used is qualitative or field.

\section{Results and Discussion}

\subsection{Victory in Islam}

The marriage is the stage before leading to marriage. Marriage can also be said with an introduction phase between a man and a woman to marry her later. Thus, marriage does not cause an attachment to the two or in other terms, marriage does not become the cause of a woman belonging to a man because there is no marriage bond there. So the marriage later can end bitterly at the end of the marriage. However, if a woman has been married to a man, the door of marriage to another man is closed as long as the marriage has not been canceled.

The word "peminangan" comes from the word "areca, ask for marriage" (verb). Marriage is a request from a man to a woman to be made as a wife. ${ }^{6}$

\footnotetext{
3 Fathur Rohman, Hukum Adat Peminangan dan Perkawinan di Komunitas Muslim Minoritas Jimbaran Bali, Al-Mazahib, Vol. 2, No. 1, 2014, p. 3.

${ }^{4}$ Djulaeka Dkk, Buku Ajar Metode Penelitian Hukum, Scopindo Media Pustaka, Surabaya, 2019, p.71.

${ }^{5}$ Sugiyono, Metode Penelitian Kuantitatif, Kualitatif dan R\&D, Alfabeta, Bandung 2009, p. 29.

6 The online version of the Big Indonesian Dictionary (KBBI), https://kbbi.web.id/pinang-2 Retrieved October 1, 2020.
} 
Whereas in the science of fiqh according to the term it means a statement or request from a man to a woman to marry her, either by the man directly or by means of a party he trusts in accordance with religious provisions. ${ }^{7}$

From the above understanding, it can be concluded that the marriage is a man asking for a woman or it could be through an intermediary (in certain societies it is sometimes represented by a religious leader). The marriage can also be done directly or with satire as explained in Surah Al-Baqarah Verse 235. ${ }^{8}$ The practice of the marriage works like that in accordance with their respective religions and customs, and in each place it is certain that they will be different in their implementation. In general, a marriage like that is where men ask women to live together in a marriage bond without any other purpose that causes harm to each party.

In essence, marriage involves two families which lead to the realization of the status of husband and wife and therefore there is the term marriage. ${ }^{9}$ The marriage, when seen from the practice, seems to be more inclined to know more deeply which is more likely to continue to occur to the marriage. In contrast to dating or ta'aruf which in our opinion is only limited to getting to know each other. But at first glance the two of them appear to be dating together or ta'aruf and then the marriage. I don't know which one is true, it seems that each individual has his own view somehow.

In some areas, marriage ceremonies are known as nakokke (in Indonesian it may mean asking whether the woman has a lover or not). Nakokke is generally just a formality in calling the stages to marriage. This is because the nakokke itself is just a binder so that no one else approaches to propose to one of the potential partners. Generally, for potential partners who have been dating (know each other better), the man usually has asked the woman to be willing to live together. Likewise, they must also have asked for permission or blessing for that. And both families know that.

\subsection{Islamic Law View of Marriage}

Rasulullah SAW said: Women are married because of four things, namely religion, lineage, wealth and beauty, so pay attention to their religion so you will be safe (Narrated by Bukhari and Muslim). ${ }^{10}$ Choosing a husband / wife candidate should be careful and not in a hurry, because the person chosen will be a companion and live together until the end of life. In addition, it is also necessary to sort out what kind of heavy weight seeds are coveted. In other words, the candidate pair at least fits the criteria or is good in general.

\subsubsection{Choosing a Husband Candidate}

\footnotetext{
7 Djaman Nur, 1993, Fiqh munakahat, Toha Putra Semarang, Semarang, p. 13.

8 A. Darussalam, Peminangan Dalam Islam (Perspektif Hadis Nabi SAW), Tahdis, Vol. 9, No. 2, 2018, p. 2.

9 Abdul Mutalip, Dispensasi Nikah dalam Upaya Menekan Angka Perceraian, Jurnal Perkembangan Hukum, Vol. 2, No. 3, 2020, p. 279.

10 Nia Anita, 2018, Ibu, Kafahkah Madrasahmu, PT Elek Media Komputindo, Jakarta, p. 97.
} 
In choosing a prospective husband, the first should be religious because Islam is the only way that makes him safe in the world and in the hereafter. As Allah says, Surah Al-Baqarah Verse 221.

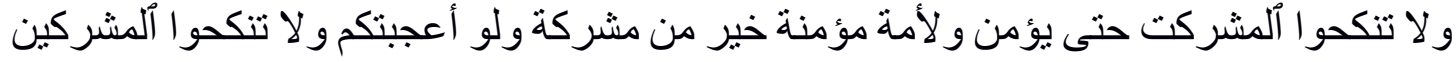

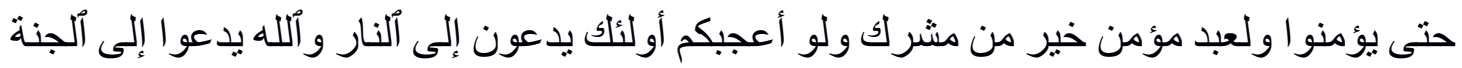

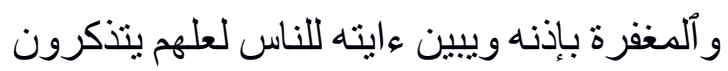

Meaning: And do not marry idolatrous women, before they believe. Indeed, a slave woman who believes is better than an idolatrous woman, even though she attracts your heart. And do not marry the polytheists (with believing women) before they believe. Surely a slave who believes is better than a polytheist, even though he attracts your heart. They invite them to hell, while Allah invites them to heaven and forgiveness with His permission. And Allah explained His verses (His commandments) to people so that they would take lessons. ${ }^{11}$

The second criterion is good character and good lineage or offspring. Because not many husbands currently abandon their wives, commit domestic violence because their characteristics are classified as bad. Violent and violent, especially mild-handed, is very frightening. Likewise the lineage or descent also needs attention. For example, do not choose a prospective husband who has a line of arrogance, envy and others because of environmental factors. That nature will carry over in the household. So that the household feels chaotic.

In this case Rasulullah SAW warned his people in choosing a husband. He once said which means: whoever marries his sister to a fasiq man means that he has broken the ties of his family. (Narrated by Ibn Hibban). Based on the hadith above, it reminds us that a family should be careful in marrying a woman. Do not marry her to a man who is fasiq because it brings division in the family. Not only affects the nuclear family, but also affects the families around it.

Al-Ghazali also expressed caution in marrying off girls. That a daughter after marriage will become a slave to her husband who will never be separated. The husband is easily mentally free whenever he likes. ${ }^{12}$ This is because the husband has the right to mentor the wife. Roughly like a slave who can't escape from his master. The wife cannot just let go. Because the one who has the right to release is the husband. You can imagine if her husband behaves badly.

\subsection{2.. Choosing a Prospective Wife}

As in choosing a husband, choosing a wife should not be arbitrary. Because the wife is a place of tranquility for the husband, a place to plant his seeds, his life partner, the mother of his future children and so on. Its role is very crucial in the household. Therefore Islam recommends that a man choose a righteous wife.

Rasulullah SAW's message for men is not to choose the wrong wife, namely stay away from you beautiful, poisonous women. Then there was a friend who asked, 0 Messenger of Allah who is this beautiful and poisonous woman? Rasulullah replied, a beautiful woman but in an evil environment. (Reported by Daruquthni). This hadith indirectly explains that the environment is a very

${ }^{11}$ Al-Qur'an, 2012, PT Cordoba Internasional Indonesia, Bandung, p. 35.

12 Abdul Haris Na'im, Fiqh Munakahat, Buku Daros Stain Kudus, 2008, p. 31. 
important factor in influencing human behavior. Therefore Rasululloh reminded not to have a wife like that. If the husband can educate her to be better, no problem. However, it is very difficult if the behavior is ingrained.

There are more tips in finding a prospective wife, because they are beautiful, obedient and trustworthy. This is in accordance with the words of the Prophet Muhammad, which means: a woman is married for four reasons, her beauty, her descendants, her assets and her religion. But choose a religious woman so that you are saved. (HR. Muttafaq Alaih). ${ }^{13}$ Rasululah SAW's next message which means: marry some girls because in fact they are more delicious in their mouths, their uterus is fertile (more capable of giving birth to many children) and they are more willing to have little wealth in the world. (HR. Thabrani). ${ }^{14}$

From the hadith above, it is clear that the hadith is the foundation for a household. But try to put the first priority is a matter of religion. Because the wife is the first teacher for the children in the future. If a wife understands religion and doesn't even have a strong religion, how will it be to educate her offspring? Then the next hadith is to try to find a potential wife who is happy with children and can have many children. This is because children are one of the healers, encouragement for their parents. Children can become medicine when their parents are in trouble.

Then the criteria for women who can be married are women, there is no law against marrying that woman. Indirectly is a woman who has not been married to another man and also that woman has not been legally married to another. Because the law is makruh, which is close to haram to propose to a woman who has first been proposed by someone else.

Meanwhile, women who cannot be married are women who are in the iddah (death / divorce) period. Because the iddah period allows the husband to reconcile to his wife. The woman has been proposed by someone else because it is unlawful if the guardian and woman have accepted another man's proposal.

The steps in proposing before the man should first look at the woman who will be proposed because this is the sunnah. This is done so that the man was sure and absolutely sure that he was the one he was aiming for. And also so that he knows that because he has seen earlier he feels he has found something or a factor that drives him to propose to her. As the Prophet Muhammad SAW said when Mughirah had proposed a woman Rasullulloh told him to see the woman he proposed so that one day he could live forever together (Narrated by Nasa'i).

Not only seeing her beauty, seeing all the limbs of a proposed woman is allowed according to the opinion of Imam Abu Daud. There are also those who recommend looking at fleshy limbs, this is the opinion of Imam Auza'i. However, according to Jumhur Ulama, it is advisable to look at the face and palms only. Because by looking at the face you will see its beauty, the palms of the hands will show the fertility of the body.

Another way to get to know our proposal is to ask neighbors or close friends of the woman who really know the nature of her character. And the source

\footnotetext{
13 Ibid., P. 30.

${ }^{14}$ Zainuddin Ibnu Abdul Aziz Al-Malybari, Irsyadul Ibad, Terj. M. Ali, Terjemah Irsyadul Ibad Penuntun Manusia ke Jalan yang Benar, Mutiara Ilmu, Surabaya, 2010, p. 546
} 
of the information mentioned above should not add to or diminish to the extent that what is being asked needs to be answered.

Generally, in a proposal there is such a thing as a ring (swap ring). That happens if the proposal has been successfully accepted. Usually this applies in only some areas or even certain people. Then why is this ring exchange done, because of the binding factor. The ring is proof that there has been a match among those who wear the ring.

Then if we feel that it does not match our proposal, do not continue and it is dangerous if it continues there will be a divorce (breaking of the marriage bond) ${ }^{15}$ due to the forced incompatibility. After the introduction process (dating), it is better to say good things, not to hurt the woman's feelings. If you have given something while proposing, then it is considered that a grant does not need to be asked again (this is the opinion of some scholars) if it is a condition for marriage then it can be asked for, it can be requested in full if the item is still there (this is Hanafi's opinion), if a man cancels then no may ask, if the woman cancels then it can be asked (this is Maliki's opinion). ${ }^{16}$

Islam is very detailed in regulating human life. Islamic law in regulating marriage issues is not a joke because the rules are in the form of revelation. We can already imagine how sacred it is, there will certainly be wisdom in its existence and of course there are things that are very important in the future for the good of humans themselves. Not only the regulation, but in the implementation by humans, especially Muslims, of course, carry out what is prescribed. Not only because you are sure of the lesson but also hope that later it will bear sweet fruit and always under His guidance and protection.

The marriage in Islam is not legislated. So that the proposed or not will not lead to law. It should be noted that although this is not the case, its implementation runs smoothly because of the very strong belief of every Muslim in carrying it out. In addition, when viewed from the point of view of betrayal or denial in the marriage it is also not arbitrary that there is a possibility of fear of reprisal at the end. Indeed, the marriage is worldly, but if God has arranged it then of course there will be a connection with the afterlife.

\subsection{The View of Customary Law in Indonesia on Marriage}

According to MM Djojodigoeno, customary law is a law that does not originate from regulations made in advance by the government in the form of legislation. ${ }^{17}$ Customary law operates from the community itself, which becomes the rules of their life, which later they themselves will obey or support its existence based on their own beliefs. So the law does not require the role of the authorities to set the rules. Then customary law in its existence is rarely codified but its existence always exists in society and runs in it.

\footnotetext{
15 Ahmad Nafhani, Implementasi Talak Ba'in Sughro Pada Suami Murtad, Jurnal Perkembangan Hukum, Vol. 2, No. 2, 2020, p. 98.

${ }^{16}$ Abdul Haris Na'im, Op.cit, p. 31-40.

17 Dominikus Ratos, Hukum Adat di Indonesia, Laksbang Justitia, Surabaya, 2014, p. 15.
} 
Customary law can be a social control system in society. Customary law can regulate or control society so that it does not deviate from behavior and of course can be directed. As little as possible, deviations in society will be controlled so as not to cause division or conflict as a result of shaking the social foundation in society. In the future, the community, with the existence of customary law, will be in harmony with each other without any separation between each individual in it. Based on the values, principles and norms that run in society and are recognized by them, customary law will be more pronounced in people's lives.

Each region can be ascertained to have different customary laws from other regions. The difference is very understandable considering the values that exist in each region are different and therefore it affects the practice of marriage to be not only limited to being a husband and wife. ${ }^{18}$ In connection with the proposal in each region, there may be differences. In the author's own area, namely Kudus Regency, presumably the term of the marriage ceremony itself varies, among others: sermon, naleni, nakokke and even the wedding itself This difference depends on the beliefs of each individual if from religious circles, the use of khitbah and the abangan circles, for example using naleni, nakokke and peminangan. In practice, it varies.

Islamic religious circles in carrying out sermons usually tend to be more inclined to Islamic rules and the local customs are used very little. In the process of the sermon, we will go through several processes, which is certain that there will always be a matching weton in it, considering that the author's area is Java. If it is agreed that the weton of the two candidates will bring "goodness", then the process will be continued with the search for a good day for the next process of application and marriage. Religious circles still use this kind of kejawen, especially from abangans who are still thick with Kejawen itself, which is even more complicated to the point that there are even rules about where to sit when the nakoke should face and which direction the host should take to that detail.

In Kutuk Village, Undaan District, Kudus Regency, for example, there is a unique term in marriage. The terms are kudangan and metu ngarep opo metu mburi. Kudangan according to the large Indonesian dictionary is something that is given by the groom to the bride at the request of the bride. ${ }^{19}$ Tradition in the village is a kind of meaning of kudangan, but the request begins with a marriage made by a man to a woman and her parents on the condition that they fulfill the meal. Kudangan itself comes from a long time ago when the woman was a child, it was always in the warehouse (on the parents' lap while shaking it while giving a will to the child for tomorrow when she was married asking for "this" for example). So the snack itself means something that the woman likes.

Furthermore, if the man is willing to give what the woman likes, the marriage will continue to a further process. Kudangan is more often done by people whose economies can be said to be middle to lower class, but there are also

18 Muhammad Khoiruddin, Pandangan Hukum Islam Tentang Praktik Hukum Adat Pernikahan Ngelangkahi Mendahului Saudara Sekandung Di Dukuh Babadan Sumberjo Kecamatan Bonang Kabupaten Demak, Konferensi Ilmiah Mahasiswa Unissula, 2019, p. 1235.

19 The online version of the Big Indonesian Dictionary (KBBI), https://kbbi.web.id/kudang, Retrieved October 1, 2019. 
many lower classes who do not practice this custom. The request of the woman who walked there was not too burdensome, even if we gave an example of asking for a motorbike it seemed too expensive in the snack category itself. If you say that in the area, it seems as if there are differences in castes, we don't think so considering there is no caste word there. If you want to propose to a woman from a middle to upper economic family, you must prepare yourself to prepare everything if she comes from a lower middle class family.

The second is metu ngarep opo metu mburi. The term, if interpreted into Indonesian, means through the front route or the back route. The point of this statement is that when the man comes to ask for the woman to be married to, the woman's parents say which route was taken. If you want to go through the front lane, it means that the man has to give one buffalo and if you go through the back lane, he can't afford to give the buffalo. If you are unable to provide the buffalo, it can be said that the proposal was rejected. This second term is commonly used by people from the upper middle class (the rich). Over time, the requirements for buffalo were deemed inappropriate, so they were often replaced by motorbikes, cars or even rice fields. ${ }^{20}$

The marriage comparison in customary law has a worldly inclination. Sometimes it also tends to mystical things that smell of Kejawen (in Java). Unlike the marriage according to Islamic law, marriage in customary law emphasizes permanence in the world as well as the terms of calculations such as primbon. The calculation also does not come from God's orders or His prophet, but from the standards that are considered effective or effective to do or not. All of that is purely artificial or human engineering from ancient times that is believed from generation to generation until now. The truth cannot be accounted for, considering that much has happened and also has not happened. So it is clear that marriage in customary law relies more on faith alone, which is different from belief in God.

\section{Closing}

A marriage is a man asking for a woman or it can be through an intermediary (in certain societies it is sometimes represented by a religious leader). The practice of the marriage works like that in accordance with their respective religions and customs, and in each place it is certain that they will be different in their implementation. The marriage comparison in customary law has a worldly inclination. Sometimes it also tends to mystical things that smell of Kejawen (in Java). All of that is purely artificial or human engineering from ancient times that is believed from generation to generation until now. The truth cannot be accounted for, considering that much has happened and also has not happened. So it is clear that marriage in customary law relies more on faith alone, which is different from belief in God.

\section{References}

\footnotetext{
20 Interviews with Mbah Sawir, Mbah Salim and Pak Suparno, residents of Kutuk Village, Undaaan District, Kudus Regency on Sunday, October 11, 09.00 WIB.
} 


\section{Kitab and Hadith:}

[1] Al-Qur'an Surah Al-Baqarah Verse 221

[2] Hadith of the Messenger of History from Muttafaq Alaih (Bukhari and Muslim).

[3] The Hadith of the Prophet Muhammad Thabrani

[4] The Hadith of the Prophet Muhammad Ibn Hibban

[5] The Hadith of the Prophet Muhammad Dar Al-Quthni

[6] The Hadith of the Prophet Muhammad Nasa'i

\section{Scientific Journal and the Internet:}

[1] Abdul Mutalip, 2020, Dispensasi Nikah dalam Upaya Menekan Angka Perceraian, Jurnal Perkembangan Hukum, Vol. 2, No. 3, http://jurnal.unissula.ac.id/index.php/ldj/article/view/11800.

[2] Ahmad Nafhani, 2020, Implementasi Talak Ba'in Sughro Pada Suami Murtad, Jurnal Perkembangan Hukum, Vol. 2, No. 2, http://jurnal.unissula.ac.id/index.php/ldj/article/view/11444.

A. Darussalam, 2018, Peminangan Dalam Islam (Perspektif Hadis Nabi SAW), Tahdis, Vol. $9, \quad$ No. 2, 20 http://journal.uinalauddin.ac.id/index.php/tahdis/article/view/7537.

[3] Fathur Rohman, 2014, Hukum Adat Peminangan dan Perkawinan di Komunitas Muslim Minoritas Jimbaran Bali, Al-Mazahib, Vol. 2, No. 1, http://ejournal.uin-suka.ac.id/syariah/almazahib/article/view/1401.

[4] Muhammad Khoiruddin, 2019, Pandangan Hukum Islam Tentang Praktik Hukum Adat Pernikahan Ngelangkahi Mendahului Saudara Sekandung Di Dukuh Babadan Sumberjo Kecamatan Bonang Kabupaten Demak, Konferensi Ilmiah Mahasiswa Unissula, http://jurnal.unissula.ac.id/index.php/kimuhum/article/view/8253.

[5] Muhammad Maulana Firdaus, 2020, Studi Perbandingan Alasan Penghapusan Pidana Menurut Kitab Undang-Undang Hukum Pidana (KUHP) dan Hukum Pidana Islam dalam Rangka Pembaharuan Hukum Pidana Nasional, Jurnal Hukum Unissula, Vo. 36, No. http://jurnal.unissula.ac.id/index.php/jurnalhukum/article/view/5346.

[6] Kamus Besar Bahasa Indonesia (KBBI) versi online, https://kbbi.web.id/kudang, (Accessed October 1, 2020)

\section{Books:}

[1] Anita, Nia. (2018). Ibu, Kafahkah Madrasahmu. Jakarta: PT Elek Media Komputindo.

[2] Na'im, Abdul Haris. (2008). Fiqh Munakahat. Kudus: Buku Daros Stain Kudus.

[3] Nur, Djaman. (1993). Fiqh Munakahat. Semarang: Toha Putra Semarang.

[4] Ratos, Dominikus. (2014). Hukum Adat di Indonesia. Surabaya: Laksbang Justitia.

[5] Zainuddin Ibnu Abdul Aziz Al-Malybari. (2010). Irsyadul Ibad, Terj. M. Ali, Terjemah Irsyadul Ibad Penuntun Manusia ke Jalan yang Benar, Mutiara Ilmu, Surabaya, Cetakan Pertama. 


\section{Regulations:}

[1] 1945 Constitution of the Republic of Indonesia

[2] Act of the Republic of Indonesia Number 16 of 2019 concerning Amendments to Act No. 1 of 1974 concerning Marriage.

[3] Regulation of the Minister of Religion Number 20 of 2019 concerning Marriage Registration. 